\title{
Gezondheid en milieu : meer dan een getal
}

Citation for published version (APA):

Ginjaar, L. (1992). Gezondheid en milieu : meer dan een getal. Rijksuniversiteit Limburg. https://doi.org/10.26481/spe.19920424lg

Document status and date:

Published: 24/04/1992

DOI:

10.26481/spe.19920424lg

Document Version:

Publisher's PDF, also known as Version of record

\section{Please check the document version of this publication:}

- A submitted manuscript is the version of the article upon submission and before peer-review. There can be important differences between the submitted version and the official published version of record.

People interested in the research are advised to contact the author for the final version of the publication, or visit the DOI to the publisher's website.

- The final author version and the galley proof are versions of the publication after peer review.

- The final published version features the final layout of the paper including the volume, issue and page numbers.

Link to publication

\footnotetext{
General rights rights.

- You may freely distribute the URL identifying the publication in the public portal. please follow below link for the End User Agreement:

www.umlib.nl/taverne-license

Take down policy

If you believe that this document breaches copyright please contact us at:

repository@maastrichtuniversity.nl

providing details and we will investigate your claim.
}

Copyright and moral rights for the publications made accessible in the public portal are retained by the authors and/or other copyright owners and it is a condition of accessing publications that users recognise and abide by the legal requirements associated with these

- Users may download and print one copy of any publication from the public portal for the purpose of private study or research.

- You may not further distribute the material or use it for any profit-making activity or commercial gain

If the publication is distributed under the terms of Article $25 \mathrm{fa}$ of the Dutch Copyright Act, indicated by the "Taverne" license above, 
Gezondheid en miliẹ: meer dan een getal

Rede, uitgesproken ter gelegenheid van de aanvaarding van het ambt van buitengewoon hoogleraar Milieugezondheidkunde aan de Rijksuniversiteit Limburg, 24 april 1992

Dr L. Ginjaar 


\section{Gezondheid en milieu: meer dan een getal}

Mijnheer de Rector Magnificus, dames en heren,

Enkele krantenkoppen": "Verband milieuvervuiling en slechte gezondheid vrijwel nooit vast te stellen". "Aantal slachtoffers milieuvervuiling loopt mogelijk in de daizenden". "Bevolking wreest gezondheidsschade door milieuverontreiniging".

Het zijn aanduidingen over de onzekerheid die bij de bevolking bestaat met betrekking tot de invloed van milieuverontreiniging op de gezondheid. Sommigen wijten - zo niet alle - dan toch veel kwalen aan ons milieu. Anderen zijn van mening dat het op zijn slechtst allemaal best meevalt. Het is daarom niet verbazingwekkend, maar wel verheugend, dat dit onderwerp steeds meer belangstelling krijgt. $^{2}$

In dit half uur wil ik enkele aspecten in vogelvlucht nader belichten, zonder daarbij uitzicht op meer zekerheid te kunnen bieden. En waarbij ik vooralsnog in het ongewisse laat of er in de titel val de voordracht sprake is van één getal dan wel een getal.

Allereerst een korte terugblik.

De mens heeft altijd blootgestaan aan invloeden van buiten. Oude kronieken verhalen ons daarover, bijvoorbeeld hoe reeds in de $13^{\circ}$ eeuw de koning van Engeland wegens overmatige luchtverontreini- 
ging zijn zetell van Londen nara Nottingham verplaatste. Of hoe in de $17^{*}$ eeu $w$ in onze binnensteden keuren werden witgevaardigd om waterverontreiniging tegen le gan, bijyoorbeeld om afval water van bierbrouwerijen, of zeepsop van weverijen of zelf menselijke witwerpselen niet langer in dezelfde gracht to lozen als die waaruit ook het drinkwater geput werd. Ook in de $18^{\circ}$ eeuw leefden de mensem nog "in een lucht die bezwangerd was met de geur vam rottende stoffen en met ziekteverwekkende bacterien". "Zij waren omgeven met hopen afval en mer opperwlaktewater van erbarmelijke kwaliteit." Meer onwelriekende beschrijvingen uit die tijd (overigens onder het motto Pestdamp en Bloesemgeur ${ }^{3}$ ) wil ik $U$ besparen.

De Staatsregeling van 1798 van de Bataafse Republiek zegt dat de regering "door heilzame wetten, hare zorg uit(strekt) tol alles wat in het algemeen de gezondheid der ingezetenen kan bevorderen door wegruiming, zoveel mogelijk, van alle belemmeringen". Aandacht moet besteed worden aan "alles wat strekken kan tot bevordering van de gezondheld" "er moet acht worden gegeven op luchtbedervende en besmettelijke oorzaken van ziekten" en "am al hetgeen de lucht met schadelijke dampen vervult", er moet gelet worden "op alle soorten van spijzen en dranken en, voor zover derzelver aard, hoedanigheid of bereiding voor de gezondheid madelig kunnen zijn"

In 1815 schreef een ordonnantie voor dat voor een hinderlijke activiteit een vergunning nodig was, welke eerst kon worden verleend madat de omwonenden waren gehoord en van eventuele be$z w a r e n$ proces-verbaal was opgemaakt. Kortom, Milieuwetten en Warenwet in wording, met vergunningen, inspraak en bezwaarschriften.

Op zeker moment - zo omstreeks 1830 , in het begin van de indus uriele revolutie - ontstond de "sanitaire beweging"; de roep om betere hygiènische omstandigheden werd steeds luider, mede als gevolg van een immer groter wordend inzicht in het verband tussen deze omstandigheden en de toestand van de volksgezondheids. Later werd ook de invloed van de sociaal-economische positie onderkend; er werd zelfs gesproken wan een "hygiènische klassetegenstelling" (sociaal-economische gezondheidsverschillen avant la 
lettre!); "een goede woning, juiste voeding, gezonde arbeid, reinheid van lichaam en zeden" werden alls essentiele voorwarden gezien voor een goede gezondheid.

Vanaf het midden van de vorige eeuw ging de overheid zich dan ook actief bezighouden, met het formuleren van een hygienisch beleid, vooral dankzij de inspanningen van Thorbecke vanuit de verantwoordelijkheid van de overheid voor het algemeen belang en dus voor de volksgezondheid. Tot dit beleid werd gerekend vleeskeuring, verzameling van huishoudelijk afval, riolen en riolisatie, en "acht geven op de gevaren der handwerken en beroepen, die stof, damp of vocht verwekken ${ }^{1 "}$, etc. ${ }^{7}$ Maar ook toen ging - net als nu niet alles even voorspoedig als men zou wensen ${ }^{3}$. Feit is wel dat in die tijd de grondslag werd gelegd voor een goed beleid op het gebied van de openbare gezondheidszorg, waarvan we nu nog de vruchten plukken.

Als we nu de sprong naar de twintigste eeuw maken, dan zien we vanaf de jaren zestig een sterke groei van het milieubewustzijn. Was vroeger slechts de gezondheid van de mens in het geding, allengs werd duidelijk dat bevolkingstoename, technologische ontwikkeling en schaalvergroting tot problemen van veel wijdere betekenis leiden. Van geluidhinder in de disco tot het gat in de ozonlagg, van het locale naar het mondiale, van het omkeerbare tot het nietomkeerbare, van het humane tot het ecologische. De noodzaak van regelgeving werd andermaal erkend, gaande van de Algemene Politie Verordening voor de disco tot het verdrag van Montreal voor het ozongat.

Menselijke activiteiten beinvloeden niet meer slechts de kwaliteit van ons milieu - zoals tot een a antal decennia geleden - maar leiden nu tot wezenlijke veranderingen. De daaruit volgende noodzaak van een milieubeleid laat zich kernachtig in drie doelstellingen formuleren:

- het in stand houden van natuurlijke kringlopen als essentiele voorwaarde voor het bestaan van mens, flora en fauna;

- handhaven of verbeteren van de milieukwaliteit niet alleen als voorwaarde voor de menselijke gezondheid, maar ook voor de ontplooiling van mensen;

- het handhaven of verbeteren van het milieu als factor van economisch belang. 
Ik zal mij nu beperken tot de tweede doelstelling, te weten die welke betrekking heeft op de relatie tussen milieu en gezondheid. De vraag is overigens warover wij ons meer zorgen dienen te maken: over de schade voor de mens van toxische stoffen, danwel de grote achteruitgang van soorten en ecosystemen."

In het volgende zal ik in het kort op drie aspecten ingaan. In de eerste plaats de wrag wat wij weten over millieu-effecten op de gezondheid; vervolgens enkelle woorden ower de vraag hoe wij met risico's in algemene zin omgaan, waarna ik nog enige aandacht zal geven aan het risicobeleid ten opzichte van stoffen.

De Wereldgezondheidsorganisatie stelt dat: "Health is a state of complete, mental and social well-being, and not merely the absence of disease or infirmation", een ruime, statische en ietwat utopisch aandoende omschrijving. In ons dagelijks leven zal eenieder dit begrip niet aanstonds in verband zien met koele ciffers over sterfte en zickte, maar weeleer met het subjectieve al of niet zich lekker voelen, wel of geen klachten hebben.

Gezondheid is meer dan een toestand en moet eerder gezien worden als een dynamisch evenwicht, als resultante van de wisselwerking tussen biologische gegevenheden en de daarop inwerkende factoren. Dit evenwicht is bepalend voor iemands functioneren, zowel in fysieke, psychische als sociale zin. ${ }^{10}$ Dat functioneren wordt gewardeerd op een schaal die loopt van goed tot slecht; een waardering, die overigens afhankelijk is van heersende culturele en matschappelijke opvattingen.

Gezonde mensen hebben een zekere weerstand of een zeker incasseringsvermogen om bedreigende factoren het hoofd te bieden (immunsysteem, ontgiftende enzymen, mentale kracht, stressbestendigheid). Dat vermogen kan verminderen zonder dat nog van een warneembaar gezondheidseffect sprake is. Overbelasting leidt dan tot en probleem: het individu is uit evenwicht met zijn omgeving. Veel ziekteprocessen zijn niets anders dan een gevecht om dit evenwicht te herstellen. 
Gezondheid wordt bepaald door tal van factoren. Er zijn daarbij vijf categorieen te onderscheiden":

- endogene factoren, die genetisch bepaald zijn;

- exogene factoren van biologische, chemische en fysische aard;

- leefstijl en gedrags patroon, bijvoorbeeld roken, alcoholgebruik, voeding, etc.;

- sociaal-economische status, samenhangend met factoren als opleiding, beroep en inkomen;

- curatieve gezondheidszorg.

Er bestaat een onmiskenbare wissel werking tussen deze factoren. Vooral exogene factoren, leefstijl en gedragspatroon kunnen samen met de sociaal-economische positie tot een cumulatie van nadelige invloeden op de gezondheid leiden; het is niet moeilijk dergelijke situaties aan te wijzen. Door deze wisselwerkingen zal het echter waak niet mogelijk zijn om beslissende factoren scherp te onderscheiden, en vervolgens daarop een beleid te baseren.

Bezien wij de huidige algemene gezondheidstoestand van de bevolking, dan kunnen wij alleen mar constateren, dat die goed is, althans voor zower het de levensverwachting betreft. Bij mannelijke pasgeborenen is deze tegenwoordig in ons land 73 jaar, bij vrouwelijke 80 jaar; in 1910 waren deze cijfers respectievelijk 56 en 58 . We naderen langzamerhand de biologische grens. Mannen blijuen tegenwoordig gemiddeld tot hun zestigste levensjaar verschoond van gezondheidsbeperkingen, vrouwen tot hun achtenvijfstige. ${ }^{12}$ Het is duidelijk dat de $\mathrm{kwaliteit}$ wan ons bestaan sterk is verbeterd. Het gevolg van - naast onze gezondheidkundige voorzieningen - dezelf de ontwikkelingen die thans ook ons milieu zo verregaand bedreigen.

Beschikbare gegevens bieden geen duidelijkheid over een mogellijke negatieve invloed van milieuverontreiniging op de algemene gezondheidstoestand. ${ }^{13}$ Anders ligt dit echter in de landen van Midden-en Oost-Europa - of in steden als Mexico-city en Cairowaar het geheel van levens-en milieu-omstandigheden kan leiden tot een duidelijke vermindering van de levensverwachting. Vergeleken hiermee leven wij in een "schoon" land. 
Niettemin kunnen al of niet herkenbare factoren wel degelijk inwloed hebben op de gezondheidstoestand van individuen of groepen individuen. Specifieke vormen van milieuverontreiniging met soms aantoonbare lichamelijke of geestelijke gezondheidsschade zijn, bijvoorbeeld, hinder door lawaai, stank, functieverlies van de longen bij blootstelling aan ernstige luchtverontreiniging zoals smog of de verspreiding van asbest, functieverlies van bijvoorbeeld de nier door blootstelling aan cadmium. Maar in het algemeen geldt dat wragen van de bevolking of bepaalde ziekteverschijnselen een gewolg van milieuverontreiniging zijn, danwel dat bepaalde milieuwerontreinigingen tot ziekte zullen leiden, veelal niet of nauwelijks te beantwoorden zijn. Ik denk dat dit ook zo gezegd moet worden in plats wan het laten horen van als geruststellend bedoelde bromtonen. Een - veel genoemd - voorbeeld moge dit verduidelijken.

Medio 1985 ontdekten in Aalsmeer de ouders van een aan leukemie overleden jongen dat er binnen een straal van én kilometer elf patiènten met vergelijkbare ziektebeelden waren. De verschijnselen werden door hen in verband gebracht met een waterplas, die in open werbinding zou staan met voormalige stortplaatsen voor afgewerkte olie en bestrijdingsmiddelen. Voorzichtige conclusies van verricht onderzoek waren dat zwemmen in de verontreinigde plas, intensief contact met bestrijdingsmiddelen en olieprodukten "mede een rol gespeeld kan hebben bij het ontstaan van kwaadaardige bloedaandoeningen". Anderzijds werd door andere onderzoekers geconstateerd dat uit de literatuur niet duidelijk blijkt dat leukemie kan worden veroorzaakt door de stoffen waarvan sprake was. De ziektebeelden (leukemie en lymfomen) waren onderling toch wel enigs zins verschillend. En tenslotte, het aantal patiënten was te gering om met grote zekerheid conclusies te kunnen trekken; hoe kleiner het antal ziektegevallen, hoe groter de kans dat toeval een rol speelt.

Een ander voorbeeld. Zo bleek in een onderzoek in Californië rond een vuilstort de sterfte, het aantal miskramen, het voorkomen van kanker en van leverziekten normaal te zijn. Anderzijds waren er meer dan normal klachten over hoofdpijn, zere keel, slaapproblemen, irritatie van ogen en huid en vermoeidheidsverschijnselen, vooral in wijken met stankoverlast. ${ }^{4}$ 
Wij moten constateren, dat wij over yeel aspecten gewoon nog niels weten. Te denken is bijvoorbeeld an de interactie tussen milieufactoren, zoals gebleken is bil de combinatie van CARA, binnenthuismilieu en allergenen. Welke is de invloed van milieuverontreiniging bij de verouderingsprocessen en -ziekten zoals Alzheimer, zoals die zich bij een vergrijzende bevolking voordoen, welke is de invloed op reumatische a andoeningen. Over de eventuele schade aan de menselijke gezondheid op langere termijn valt weinig te zeggen.

Velen denken echter het eerst aan milieuverontreiniging als oorzaak van ziekte, met name het optreden van kanker, terwijl er toch duidelijke anwijzigingen zijn dat slechts $2 \%$ procent van alle gevallen veroorzaakt wordt door stoffen in het milieu; voeding, roken, alcoholgebruik, etc., hebben een veel grotere invloed. " $\mathrm{Maar}$ ook als het gaat om de invloed wan toevoegingen aan en verontreinigingen van voedsel op de gezondheid, bestaat deze beduchtheid, terwijl de wetenschap juist het gebruik wan verkeerde voeding (sgewoonten) aanwijst; de risico-schatting van het publiek wijkt duidelijk af van die van de wetenschap. ${ }^{16}$

Dit brengt mij op het tweede aspect dat ik naar voren wil brengen, te weten de vraag hoe wij metrisico's omgaan. De Gezondheidsraad zegt het aldus: "Het antwoord op deze vraag hangt sterk af van de groep die hierover een antwoord tracht te formuleren. Een rol speelt immers de manier waarop men aankijkt tegen de diverse onzekerheden van het probleem" " Naast de technische wardering van het risico, is er ook de subjectieve risicobeleving, zoals ik die zoéven noemde. Wat bestuurders of deskundigen zien als een verwarloos baar of zelfs aanvaardbaar risico, ervaren burgers veeleer als een potentiële dreiging.

De beleving van veiligheid door burgers is gerelateerd an een veelheid van factoren. Zo hangt de wijze warop onveiligheid door het grote publiek ervaren wordt, niet logisch samen met de feitelijke risico"s; was dat well het geval dan zou niemand meer roken. De anvaardbaarheid van vrijwillig aanvaarde risico's is veel groter 
dan die van opgedrongen risico's. Omgevingsrisico's bij een industriêle onderneming worden door werknemers meer aanvaardbaar geacht dan door niet-werknemers.

Belangrijk is ook het vertrouwen in bestuurders en deskundigen. Mensen willen duidelijkheid en zekerheid, ook ower onzekerheden. Krijgt men die niet, dan kunnen ongeloof en misverstanden ontstaan. Men gelooft daarbij niet meer in gemakkelijk uitgesproken geruststellingen van deskundigen of bestuurders. Illustratief is het volgende: de deskundige meent dat de kans zo klein is, dat het ongeval in de praktijk niet zal geschieden. "Kan het niet gebeuren", zo vraagt de moeder van een baby en twee kleuters achter in de zaal van de hoorzitting. "Nou nee, helemaal uitgesloten is het niet, maar de kans is erg klein", is het antwoord. "Dus het kan morgen gebeuren", zegt de moeder. "Nou, helemaal ... etc.". Thuis zegt zij tegen haar man dat het morgen wel eens zou kunnen gebeuren. ${ }^{18}$

Het formele proces van de beoordeling van risico's van maatschappelijke activiteiten kent twee stappen. De eerste - wetenschappelij$k e$ - fase is die van de rationele beoordeling van wetenschappelijke gegevens over het bewuste risico. De tweede fase is van maatschappelijke aard, waarbij besluiten moeten worden genomen over de aanvaardbaarheid van het betreffende risico. Deze besluitvorming is niet alleen gebaseerd op gezondheidkundige overwegingen, maar ook op overwegingen van economische, technische en politieke aard.

In beide stappen is niet te ontkomen aan een reductie van de werkelijkheid om de ingewikkeldheid van de probleemstelling hanteerbaar te maken. Een klemmende vraag is onmiddellijk in welke mate die vereenvoudigingen toelaatbaar zijn. Het inzichtelijk maken van die keuzen en vereenvoudigingen is van groot belang, ook en vooral voor buitenstaanders.

Even belangrijk is de strikte scheiding tussen de twee fasen. Vaak wordt aan een wetenschappelijk oordeel een besluitwormende lading gegeven. Omdat, bijvoorbeeld, besluitvormers an het werk van de wetenschapsmensen deelnemen. Of omdat de laatsten menen, dat zij bij uitstek geschikt zijn om te beoordelen wat maatschappelijk aanvaardbaar is en wat niet. Ik denk dat in beide gevallen de duidelijkheid en de zuiverheid van het proces in het 
gedrang komen. Zulk een vermenging van wetenschappelijke evaluatie en maatschappelijke besluitvorming acht ik onjuist.

Het vigerend risicobeleid ${ }^{19}$ van de Nederlandse overheid komt er op neer dat voor de risico's, verbonden an mogelijke grote ongevalssituaties, maar ook voor de risico's verbonden aan de blootstelling aan stoffen, straling, geluid, stank, etc., twee absolute grenzen gehanteerd worden. De eerste is het maximaal toelaatbaar risico (MTR), waarboven het risico verbonden aan de activiteit of blootstelling aan een agens ongeacht het maatschappelijk nut onaanvaardbaar wordt geacht; het tweede is het verwaarloosbaar risico (VR), waarbeneden geen als nadelig te waarderen effecten optreden, en dus de activiteit of blootstelling zonder meer anvaardbaar is. Tussen beide niveau's bestaat een verschil van een factor 100 . In het tussengebied, het zogenoemde grijze gebied, is een afweging over voor-en nadelen noodzakelijk. Altijd met het streven - door het treffen van de nodige maatregelen - het risico zo laag mogelijk te doen zijn, en het verwaarloosbaar niveau te doen naderen.

Voor calamiteiten en voor blootstelling aan kankerverwekkende stoffen of ioniserende straling is het gehanteerde maximaal toelaatbare individueel risico vastgelegd als bovengrens voor een bepaalde sterftekans, te weten de extra sterftekans van én op de miljoen mensen per jaar. Voor blootstelling aan overige toxische stoffen is het gelijkgesteld aan de zogenoemde gezondheidkundige advieswaarde. Voor ecosystemen geldt een maximaal toelaatbaar risico waarbij aan $95 \%$ van de soorten in een ecosysteem bescherming wordt geboden. Het zal aanstonds duidelijk zijn, dat deze risicomaten niet op een lijn gesteld kunnen worden. Mogen zij beleidsmatig gelijkwaardig zijn, naar de effecten zijñ zij onvergelijkbaar. Er kan dus geen sprake zijn van één inhoudelijke "maatlat" voor risico's verbonden aan ongelijksoortige activiteiten en agentia.

Het maximaal toelaatbaar niveau voor het individueel risico bij mogelijke grote ongevalssituaties is gebaseerd op het feit dat jongeren tussen 12 en 16 jaar de minst kwetsbare groep in de samenleving vormen in vergelijking met andere leeftijdscategorieen, met 
een individueel overlijdensrisico van ến op de tienduizend per jaar. Belleidsmatig - en arbitrair - is vastgesteld dat ten gevolge van een ongeval niet meer dan $\mathbb{1 \%}$ aan dit sterftecijfer mag worden toegevoegd; dat will zeggen een individueel overlijdensrisico van één op een miljoen per jaar als maximaal toela atbaar individueel risico. Ter vergelijking moge dienen dat het risico bij het werken in een veilige industrie eveneens een op tienduizend per jaar is; automobilisten hebben welhast een tweemaal 20 groot risico, het werken in een gevaarlijke bedrijfstak brengt een vijfmaal zo groot risico met zich mede.

Voor carcinogene - beter gezegd genotoxische - stoffen is in het verlengde van deze benadering het maximaal toelaatbaar indivueel risico vastgesteld op de kans op 1 extra dodelijk verlopend kankergeval per miljoen mensen per jaar. Ik wil er echter op wijzen, dat vergelijking wan deze risicomaat met die bij grote ongevalssituaties niet mogelijk is . ${ }^{20} \mathrm{Er}$ is namelijk geen rekening gehouden met het feit dat bij blootstelling aan bijvoorbeeld geringe concentraties van stoffen de gevolgen een gans andere verdeling over de tijd te zien geven als vrijwel onmiddellijke sterfte na een explosie ${ }_{\text {in }}$ met andere woorden pas later in het leven optreden.

Bij het uitdrukken en beoordelen van risico"s uitsluitend in termen van sterftekansen wordt geheel en al voorbijgegaan aan andere factoren die in het geding kunnen zijn: ziekte invaliditeit, stress, angst, onzekerheid. Kortom, al die factoren die kunnen bijdragen tot het niet in fysiek, psychisch en sociaal opzicht goed functioneren. Het verdient dan ook aanbeveling dit aspect van de vermindering van het aantal te verwachten levensjaren en de kwaliteit daarvan (naar kwaliteit gewogen levensjaren) mede in beschouwing te nemen als het gaat om het schatten van risico's.

Voor calamiteiten geldt dan bovendien nog dat er ook andere gevolgen kunnen zijn dan ziekte en sterfte. En het zijn juist die andere effecten die onder omstandigheden wellicht de de doorslag kunnen geven bij de aanvaardbaarheid van potentiele risico's (vergelijk de naweeèn van matschappelijk grote accidenten als die in Tsjernobyl). Bovendien is geen vergelijking mogelijk met andere potentieel calamiteuze situaties, die bijvoorbeeld grote nadelige invloed op het ecosysteem kunnen hebben. Ik verwacht dat de Gezondheids- 
raad hieraan binnenkort wijze woorden zal wijden.

Tenslotte het derde aspect. Bij het beoordelen van de risico's van stoffen gat het in de eerste fase om het waststellen van gezondheidkundige advieswaarden. Hieronder wordt, aldus de Gezondheidsraad, verstaan" "de schatting wan het hoogste nog gezondheidkundig verantwoorde niveau van blootstelling aan een stof.... De waarde dient tot stand te komen op grond van een zo objectief mogelijke beoordeling van de toxicologische gegevens door deskundigen met inachtneming van een velligheidsfactor." Vaststelling van deze advieswarden vindt plaats op basis van toxicologisch onderzoek, war mogelijk ondersteund door resultaten van humaan epidemiologisch onderzoek.

Op grond van de beschikbare gegevens wordt voor stoffen met een drempel waarde een zogenaamd no-effectlevel vastgesteld, $d$.i. is de hoogste concentratie van de stof die - over langere termijn toegediend - geen schadelijke effecten bij proefdieren teweegbrengt. Na correctie voor het verschil in lichaamsgewicht tussen proefdier en mens vertaalt men het gevonden getal naar de blootstellingsituatie voor de mens, door toepassing van een veiligheidsfactor, waarbij rekening wordt gehouden met verschillen in gevoeligheden bij proefdieren en mensen, en met onnaw wkeurigheden in meetmethoden. De aldus vastgestelde advieswaarde wordt in de tweede, normstellende, stap van het beoordelingsproces beleidsmatig vastgesteld als het maximal toelaatbaar risico, genaamd grenswarde. Het verwaarloosbaar risico dat een factor 100 lager ligt wordt streefwaarde genoemd.

Bij het afleiden van gezondheidkundige advies waarden voor carcinogene stoffen wordt anders tewerk gegaan. ${ }^{22}$ De gezondheidkundige advieswaarden voor zulk een stof is de door extrapolatie bere. kende dosis die bij levenslange blootstelling niet meer dan een extra kankergeval per miljoen mensen veroorzakt. Het is een mat die allerwegen gebruikt wordt, ook voor blootstelling aan ioniserende stralling, mar war geen enkele rationele beschouwing aan ten grondslag ligt. ${ }^{23}$ Het werd geboren toen twee Amerikaanse toxico- 
logen een extra kankergeval per honderd miljoen levenslang blootgestelden als vellig "uit de hoed toverden". Later wijzigde de Food and Drug Administration dat in én op de miljoen voor residuen yan carcinogene diergenesmiddelen in voedingsmiddelen van dierlijke oorsproing. ${ }^{24}$ Vervolgens $\mathrm{kreeg}$ dit criterium langzaam en ongemerkt een steeds meer officiéle status. Ook in ons land is dit in feite zo gebeurd.

Zoals eerder gesteld, drukt de overheid het risico anders uit, te weten een op de miljoen per jaar als maximaal toelaatbaar individueel risico, en én op de honderd miljoen per jaar voor het verwaarloosbaar risico; gemakshalve is de laatste beleidsmatig gelijkgesteld met de gezondheidkundige advieswaarde. Dit is echter een simplificatie, daar de basisgegevens levensiange of langdurige blootstelling betreffen en omrekening niet zonder meer geoorloofd is. Overigens, de grondslagen en de discussies van het begrip ét op een miljoen zijn wel heel verwarrend.

In het proces van risicoschatting bij stoffen kennen wij een aantal onzekerheden. Zoals het feit dat toxicologische proeven betrekking hebben op hoge blootstelling gedurende korte tijd; de praktijk is wak lage blootstelling gedurende langere tijd. Er zijn zelfs a anwijzigingen dat de in dierproeven gebruikte concentraties zo hoog zijn dat de gebleken carcinogeniteit niet naar lage concentraties geéxtrapoleerd mag worden. ${ }^{25}$

De wijze van blootstelling aan een stof is vaak grillig (continue of pieksgewijs), in tegenstelling tot de gelijkmatige toxicologisch onderzoek. De wijze van opname zal mede het effect bepalen.

Onze omgeving is bezwangerd met vele stoffen, waaraan wij tegelijkertijd blootstaan en vaak dan nog langs verschillende routes. Is het effect de som van de afzonderlijke effecten, of is er sprake van dan wel een versterking of verzwakking. Voorlopig houden we het maar op sommatie. ${ }^{27}$

Ook moeten we ons goed realiseren dat in het vaststellen wan de advieswarden geen rekening wordt gehouden met aspecten van neurotoxicologische, immunotoxicologische en huidtoxicologische aard. Ook overgevoligheid, subtiele effecten, worden niet in bescherming genomen.

Epidemiologisch onderzoek - dat overigens slechts waarden achteraf geeft - vergt grote populaties, wordt daarbij gehinderd door 
interveniẻrende factoren, is kostbaar, en geeft niet an hoe individuen op een expositie reageren.

Bij de beoordeling van risico's moet tevens onderscheid gemaak: worden tussen verschillende groepen uit de samenleving - kinderen, ouderen, $z$ wangeren, chronisch zieken, enz. Verder hebben de verschillende beleidsterreinem hun eigen uitgangspunten. Dit leidt bijvoorbeeld tot strengere eisen voor de bevolking als geheel in vergelijking met die welke op de arbeidsplaats gelden. Een werkne mer kan op zijn werkplek kennelijk beleidsmatig meer hebben dan daarbuiten.

Door de veiligheidsmarges hebben gezondheidkundige advieswaarden, zoals eerder gedefinieerd, en daarmede het maximaal toelatatbaar risico (de grenswaarde) veelal een conservatief karakter. Overige onzekerheden in de risicoschattingen leiden ertoe dat de streefwaarde beleidsmatig nog eens een factor 100 lager gesteld wordt. Dat is veel als het $g$ aat om normstelling met belangrijke maatschappelijke consequenties.

Risicogrenzen hebben slechts preventieve en geen voorspellende betekenis, en weten wij vaak niet welke de effecten zullen zijn als normen worden overschreden. Dat is de grote moeilijkheid bij vermeende klachten over effecten door milieuverontreiniging. Het is moeilijk duidelijk te maken aan verontruste burgers, dat het constateren van schadelijke effecten bij proefdieren helemaal niet behoeft te betekenen dat deze effecten ook bij mensen zullen optreden, maar dat anderzijds ook geen absolute zekerheid kan worden gegeven. Het feit dat onze afgeleide normstelling niet alleen zeer voorzichtig is maar ook nog veiligheidsfactoren kent zegt hen niets.

Geconcludeerd kan worden dat het schatten van risico's niet zo exact kan geschieden als wij wel zouden wensen. Resultaten van wetenschappelijk onderzoek gaan gepaard met onzekerheden, waldoor het beleidsmatig gewenste duidelijke antwoord vaak niet gegewen kan worden. Dit wordt niet verbeterd door alsmaar verfijnde modellen te ontwikkelen, maar leidt wel tot de noodzaak van inzichtelijke besluitvorming. Een sprekend voorbeeld dat zulks 
Illustreert is het volgende.

De oorspronkellike voor dioxine gekozen velligheidsfactor was niet 100 doch $250 .{ }^{23} \mathrm{Bij}$ de gebruikelijke factor 100 zou er in de omgeving van geen enkele afvalverbrandingsinstallatie een probleem zijn geweest. Anderzijds zou een factor van 500 heel Nederland hebben gereduceerd tot een gifbelt, zo luidt de redenering. ${ }^{29}$

Onjuiste risicoschattingen leiden tot onjuiste prioriteitstellingen. De beschikbare middelen worden dan gebruikt om risica's te beperken waar dit niet nodig is; in het andere viterste worden te weinig risicobeperkingen angebracht.

In de VS wordt $80 \%$ van de blootstelling van de bevolking aan benzeen veroorzakt door diffuse, niet gereguleerde bronnen, en is slechts $20 \%$ afkomstig van industriele emissies. De laatste zijn onderworpen a an een gedetalleerde regelgeving, de eerste niet.

Maatregelen om een additioneel kankerrisico van én op tienduizend naar én op een miljoen terug te brengen resulteren voor de blootgestelde populatie in een verhoging van de gemiddelde leeftijd met 1 dag. Het roken van 20 sigaretten per dag levert een gemiddelde verkorting van de levensduur van 6,4 jaar, en $20 \%$ overwicht 2,7 jaar. ${ }^{30}$ Ik geef deze getallen niet om beleidsmatige kritiek te geven; wel om nog eens de noodzaak van rationele en doorzichtige beslissingen duidelijk te maken.

Wat kunnen wij leren uit de vogelvlucht die ik voor U makte.

Er zijn geen a anwijzigingen, dat milieuverontreiniging in ons land negatieve effecten heeft op de algemene gezondheidstoestand van de bevolking. De gezondheid van individuen of groepen van individuen kan echter wel degelijk beinvloed worden. Het vaststellen van deze effecten is moeilijk, en vak onmogelijk; toch is woortdurend onderzoek in deze richting nodig. Er kunnen altijd effecten optreden die vooraf niet vermoed waren.

De nadruk op carcinogene stoffen en de relatie met sterfte doet geen recht an de overige factoren die in het geding zijn. Meer aandacht dient te worden gegeven aan effecten van neurotoxicologische en immunotoxicologische aard; ook dienen aspecten van de invloed van milieuverontreiniging op veroudering, chronische ziekten en 
verschijnselen van overgevoeligheid in beschouwing te worden genomen.

Duidelijk zal steeds moeten zijn dat advies waarden en normstelling geen voorspellende betekenis hebben, net zo min als toxicologie en epidemiologie ons de gewenste zekerheid kunnen geven. Dit brengt met zich mede de noodzaak meer andacht te besteden an bestudering van biologische processen in de mens. Collega Kleinjans zal $U$ daar verder over vertellen.

Gezondheid en milieu. Niet eén getal, noch een getal. Wel een veelheid van onderling gerelateerde aspecten. Een terrein vol voetangels en klemmen, voor de onderzoeker en voor de bestuurder.

De milieugezondheidkunde heeft daarbij geen pasklaar antwoord op de vragen die vanuit de samenleving gesteld (kunnen) worden. Om het even of deze nu betreffen de geluidhimder rond een vliegveld of de gevolgen van verontreiniging van de bodem door tolueen. $\mathrm{Zij}$ geeft geen absolute zekerheid ${ }_{*}$ zij geeft wel inzicht. Zij geeft de onzekerheden, maar zij stelt niet het beleid vast. Beleid dient niet onder de nam wetenschap gevoerd te worden.

De millieugezondheidkunde dient bij het vinden van een antwoord op de gestelde vragen over de relatie tussen gezondheid en milieu voor wetenschappelijke onderbouwing te zorgen. Zij makt daarbij gebruik van vele takken van wetenschap. Een enkele blik in het nominaal plan maakt dit aanstonds duidelijk: chemie, fysica, geografie, fysiologie, toxicologie, farmacologie, klinische deeldisciplines, immunologie, epidemiologie, statistiek, maar ook economie, wetgeving en gedragswetenschappen.

Milieugezondheidkunde is interdisciplinair, waarbij het geheel meer is dan de som der delen. Een goed samenspel tussen de verschillende disciplines is essentieel.

Een gezond millieu is geen garantie voor en goede gezondheid van het individu, maar wel een voorwarde voor het bereiken van een goede gezondheidstoestand wan de bevolking. Het is de uitdagende tak van de milieugezondheidskundigen vanuit hun expertise over de relatie tussen gezondheid en millieu daaraan bij te dragen. 
Gekomen an het einde van mijn voordracht will ik garne jegens het College van Bestuur, Bestuur en Faculteitsraad van de Faculteit der Gezondheids wetenschappen mijn erkentelijkheid wilspreken voor het feit dat zij mij de gelegenteid gaven om - zij het nog gedurende een beperkt antal jaren - tezamen met collega Kleinjans aan de opbouw en de inrichting van de studierichting Milieugezondheidkunde mee te werken.

In de tijd dat ik nu bij de Vakgroep Gezondheidsrisico Analyse en Toxicologie verkeer, heb ik grote waardering gekregen voor de inzet van de medewerkers zowel bij het onderwijs als het onderzoek. Ik ben ervan overtuigd, dat zij en alle anderen die bij de studierichting betrokken zijn er in zullen slagen de Rijksuniversiteit Limburg een uitstekende nam te bezorgen.

Ik will niet nalaten op deze plaats de medewerkers van de secretariaten van Gezondheidsraad en Centrale Raad voor de Milieuhygiène te noemen. Juist bij de voorbereiding van deze voordracht is mij weer eens opgevallen op welke voortreffelijke wijze zij inhoud en vorm geven aan de adviezen van de Raad.

En dan de studenten. Hard werkend en gemotiveerd, zo heb ik hen leren kennen, in een studie die niet alleen uitermate boeiend is, maar ook van groot belang yoor onze samenleving. Hen daarbij te kunnen begelleiden is mijeen voorrecht.

\section{Noten}

1 Milieumagazine, 1991, nr 2; Volkskrant, 3 januari 1990; Toegepaste Wetenschap TNO, 1990, nr 2.

2 Onlangs wijdde de Koninklijke Matschappij ter bevordering van de Geneeskunst nog haar $43 \mathrm{e}$ jaarcongres aan dit onderwerp; Ned. Tijdschr. Geneeskunde 135 (1991) 1844 e.v.

3 H. Lintsen, Jonas, 24 augustus 1990; in een bespreking van A. Corbin, Pestdamp en bloesemgeur.

4 A. Querido, Een eeuw Staatstoezicht op de Volksgezondheid, "s Gravenhage, 1965 . 
5 H. van Zon, Een onfrisse geschiedenis, Groningen, 1985 E.S. Houwaart, De hygiënisten, Groningen, 1990.

6 L. Heyermans, Gemeentelijke Gezondheidszorg in Nederland, Amsterdam, 1929.

R.H. Saltet, in P.H. Ritter, Ene halve eeuw 1848-1898, Amsterdam, 1898.

7 L. Ali Cohen, Handboek der Openbare Gezondheidsregeling en der Geneeskundige Politie, Groningen, 18691872.

8 W.C. Clark en R.E. Munn, ed., Sustainable development in the Biosphere, International Institute of Applied Systems Analysis Laxenburg, Cambridge, 1986.

N. Myers, The Gaia Atlas of Planet Management, Londen, 1985.

9 We moeten daarbij helaas constateren dat de benodigde ecologische en ecotoxicologische kennis niet voorhanden is voor we. tenschappelijk verantwoorde aanbevelingen met betrekking tot de bescherming van soorten en ecosystemen; dit leidt tot de situatie dat enerzijds de vraag ontstaat naar de werkelijke betekenis van het $95 \%$-beschermingsniveau, en anderzijds de overheid gedwongen is met zijn beleid voorop te lopen op wetenschappelijke discussies die nog volop gaande zijn; zo kan een schijnzekerheid ontstaan (Ecotoxicologische risico-evaluatie, advies Gezondheidsraad, 1988(24).

10 R.L. Zielhuis, Ned. Tijdsch. Geneeskunde, 49 (1971), 90, 133.

11 naar M. Lalonde, A new perspective on the Health of Canadians, Ottawa, 1974.

12 P.J. van der Maas, Lang zullen we leven, Dies-rede, Erasmusuniversiteit, 8-11-1989.

13 P.G.N. Kramers et al in Milieuverkenning II, Rijksinstituut van Volksgezondheid en Milieuhygiène, 1991.

14 G.H. McClelland et al, Risk Analysis 10 (1990) 485. 
15 R. Doll en R. Peto, Journ. Nat. Cancer Inst., 66 (1981), 1192.

16 F. ten Hoor, Landbouwk. Tijdschr, 103 (1991), 3.

17 Externe veiligheid, Gezondheidsraad, advies, 1984/35.

18 W.F. Passchier, bij gelegenheid yan de overhandiging van het NOTA-rapport "Voorlichting over risico's" aan de Voorzitter van de Tweede Kamer-commissie woor Wetenschapsbeleid, 232-1989.

19 Omgaan met risico's, Tweede Kamer, $1988-1989,21137$, nr 5 Over achtergrondaspecten is veel lezenswaardig te vinden bij S.H.C. Julsingh, De ontwikkeling van het normstellingsbeleid; de 10-6norm in perspectief; Technische Universiteit Twente, 1988 , J.C. Knijf en W.A. Smit, de Ingenieur 1991, nr 5 en C.A.J. Vlek, Beslissen over risico-acceptatie, Achtergrondstudie Gezondheidsratad A90/10.

20 G.W. Barendse, Ned. Tijdschr. Geneeskunde, 135 (1991), 865.

21 Uitgangspunten voor normstelling; inzichtelijke opbouw van advieswaarden, Gezondheidsraad, advies 1985/31.

22 Beoordeling van de carcinogeniteit van chemische stoffen II, Gezondheidsraad, advies 1988/4.

23 K.E. Kelly en N.C. Cardon, 84th Annual Meeting Air and Waste Management Association, juni 1991 .

J.V. Rodericks, et al, Reg. Tox. Pharmacol., 7 (1987), 307.

R. Wilson ${ }^{\text {ebid., } 8(1988), 267 .}$

24 Overigens geldt in de Verenigde Staten voor voedingsmiddelen de Delaney-clausule, die zégt dat stoffen die in dierproeven als carcinogeen worden aangemerkt niet in de geringste hoeveelheid in voedingsmiddelen mogen woorkomen. Deze conclusie staat thans ter discussie. 
25 Opgemerkt moet worden, dat uit deze benadering volgt dat het maximaal toelaatbaar individueel risico bij levenslange bloot stelling ến op tienduizend is.

26 B. Ames, Science, 249 (1990), 970.

27 M. Ikeda, Reg. Tox. Pharmacol., 8 (1988), 414.

$28 \mathrm{~J}$. van Eyndhoven, Vlaams-Nederlandse Studiedagen voor Sociologen an Antropologen, Amsterdam, april 1986.

29 zie A. Rip, Chemisch Magazine, april 1991, p. 181.

30 A. Cohen, et al, Journ. Occup, Medicine, 27 (1985), 543. 